\title{
IMPLEMENTASI KURIKULUM PADA SEKOLAH PENYELENGGARA PENDIDIKAN INKLUSIF
}

\author{
Anggia Ayu Sebrina \& Dadang Sukirman \\ Universitas Pendidikan Indonesia \\ e-mail: anggiaayu@student.upi.edu
}

\begin{abstract}
Abstrak
Kurikulum pada kelas inklusif dikembangkan dengan mengikuti kebutuhan dan kondisi masing-masing anak. Dengan demikian kurikulum yang digunakan adalah kurikulum modifikasi dan sebagai perwujudan sekolah ramah anak. Penelitian ini bertujuan untuk melihat implementasi kurikulum pada sekolah penyelenggara pendidikan inklusif terkait aspek perencanaan, pelaksanaan dan evaluasi pembelajaran serta faktor pendukung dan penghambat penyelenggaraan pendidikan inklusif. Penelitian ini dilakukan dengan menggunakan metode deskriptif, dan pendekatan kualitatif yang dilakukan di dua Sekolah Dasar Negeri penyelenggara pendidikan inklusif di Kota Bandung. Penggalian data menggunakan teknik wawancara, observasi dan studi dokumen. Hasil penelitian menunjukkan bahwa a) sekolah pertama belum melakukan penyelarasan kurikulum, sedangkan sekolah kedua sudah melakukan penyelarasan kurikulum dengan cara melakukan asesmen-mengembangkan program pembelajaran individual-diskusi dengan orang tua, guru kelas, dan kepala sekolah; b) kedua sekolah melakukan penyesuaian pelaksanaan pembelajaran pada pemberian materi dan evaluasi hasil belajar. Sekolah pertama, pada pelaksanaan pembelajaran di kelas yang dilakukan oleh guru kelas sepenuhnya. Sekolah kedua, pelaksanaan pembelajaran dipimpin oleh guru kelas, namun bagi peserta didik berkebutuhan khusus yang menerima materi di bawah kelas, saat pembelajaran dibimbing oleh guru pendamping khusus; c) evaluasi pembelajaran dilakukan dengan penyesuaian tingkat kesulitan pertanyaan, jumlah soal, dan cara menjawab pertanyaan disesuaikan dengan kemampuan peserta didik. d) dukungan pimpinan, rekan sejawat dan orang tua murid sangat dirasakan, sedangkan beberapa faktor yang menghambat adalah masih terdapat kebijakan yang belum komprehensif, masyarakat yang belum paham, perencanaan penyelarasan kurikulum yang belum di supervisi, sarana dan prasarana yang kurang memadai. Rekomendasi dari hasil penelitian ini adalah pemerintah melakukan sosialisasi kebijakan keseluruh pelaksana kebijakan, memperhatikan kompetensi sumber daya manusia, serta melakukan supervisi implementasi pendidikan inklusif, memberikan aturan jelas terkait dokumentasi kurikulum pendidikan inklusif.
\end{abstract}

Kata Kunci: Implementasi kurikulum, Pendidikan inklusif

\section{CURRICULUM IMPLEMENTATION IN INCLUSIVE SCHOOLS}

\begin{abstract}
The curriculum in inclusive classes is developed by following the needs and conditions of each child, thus the curriculum used is a modified curriculum and the realization of a child-friendly school. This study aims to look at the implementation of the curriculum in schools providing inclusive education related to aspects of planning, implementing and evaluating learning as well as supporting factors and obstacles to the implementation of inclusive education. This research was conducted using descriptive methods, and a qualitative approach that was carried out in two public elementary schools providing inclusive education in the city of Bandung. Researcher collect data using interview, observation and document study techniques. The results is a) the first school had not yet conducted curriculum alignment, while the second school had aligned the curriculum with
\end{abstract}


developing individual education program, by step, assement-individual learning programdiscussion the program with parents, class teachers, and principal. $b$ ) the implementation of learning in these two schools has made adjustments to the provision of content and evaluation of learning outcomes. The first school, in the implementation of classroom learning is carried out by class teacher fully. The second school, the implementation of learning is led by the class teacher, but for students with special needs who receive the material under the class, when learning is guided by a special mentoring teacher. $c$ ) Learning evaluation is adjusted to the level of difficulty of the question, number of questions, and how to answer questions is modified by looking at students' abilities. d) Support of the leaders, peers and parents is very felt, while some factors that hinder are that there are still policies that are not comprehensive, people who do not understand, the document of modified curricula have not been supervised, inadequate facilities and infrastructure. The recommendation from the results of this study is that the government disseminates policies to all policy implementers, paying attention to the competence of human resources, as well as supervising the implementation of inclusive education, providing clear rules regarding inclusive education curriculum documentation.

Keywords: curriculum implementation, inclusive education

\section{PENDAHULUAN}

Pendidikan di Indonesia saat ini menganut sistem pendidikan segregatif yang sedang berusaha menuju pendidikan inklusif. Pendidikan segregatif adalah suatu sistem pendidikan yang terpisah, yaitu pemisahan pendidikan bagi siswa cerdas istimewa dan rata-rata dengan peserta didik berkebutuhan khusus. Sedangkan sejatinya pendidikan adalah bagi seluruh masyarakat tidak terkecuali dan tidak membeda-bedakan setiap individunya, hak untuk memperoleh pendidikan tertuang pada UUD 1945 Pasal 28c Ayat (1) dan juga disebutkan dalam UU No 20 Tahun 2003 Pasal 5 tentang Sistem Pendidikan Nasional, yang menyatakan bahwa pemerintah menjamin pendidikan bagi seluruh peserta didik tanpa membedakan ras, agama, suku, gender, keterbatasan fisik dan mental. Pendidikan segregatif sudah tidak mampu lagi mengemban misi utama pendidikan, yaitu memanusiakan manusia. Sesuai dengan amanah bahwa pendidikan diperuntukkan bagi seluruh anak tidak terkecuali maka pendidikan sebaiknya menggunakan sistem pendidikan inklusif (Budiyanto dalam Garnida, 2015). Pendidikan inklusif menawarkan strategi untuk mempromosikan pendidikan universal yang efektif karena ini adalah tentang menciptakan sekolah yang menanggapi beragam kebutuhan anakanak dan masyarakat. Ini adalah tentang akses dan kualitas, yang berarti harus relevan, efektif, dan terjangkau (Stubbs, 2008). Kebijakan yang ada saat ini pun menekankan pendidikan inklusif sebagai konsep reformasi dalam pendidikan karena diakui secara internasional bahwa pendekatan pendidikan inklusif merupakan pendidikan yang memanusiakan manusia (Kiuppies \& Peters, 2014)

Pendidikan Inklusif menurut Smith (2015) adalah penerimaan anak-anak yang memiliki hambatan ke dalam kurikulum, lingkungan, interaksi sosial dan konsep (visi-misi) sekolah. Pendidikan inklusif semakin ditekankan secara internasional dengan dilakukankan kesepakatan terhadap pernyataan Deklarasi Salamanca (UNESCO) tahun 1994 di mana Indonesia menjadi salah satu peserta yang mengikuti kongres tersebut. Isi deklarasi tersebut dirangkum oleh Skjorten (2001) menyebutkan bahwa hak semua anak, termasuk mereka yang berkebutuhan temporer dan permanen untuk memperoleh penyesuaian pendidikan agar dapat mengikuti sekolah, semua anak dapat dididik walaupun mengalami hambatan belajar dan perkembangan yang sangat berat, pendidikan inklusif bertujuan menciptakan kerjasama 
bukannya persaingan. Dukungan pemerintah Indonesia dalam pendidikan inklusif adalah dengan dikeluarkannya Permendiknas No 70 Tahun 2009 tentang Pendidikan Inklusif Bagi Peserta Didik Yang Memiliki Kelainan Dan Memiliki Potensi Kecerdasan Dan/Atau Bakat Istimewa serta dukungan lain melalui bantuan dana bagi sekolah penyelenggara pendidikan inklusif. Sejak dikeluarkannya kebijakan tersebut daerah-daerah mulai memberikan perhatian terhadap pendidikan inklusif, dan berdasarkan data yang diperoleh dari Direktorat Pembinaan Pendidikan Khusus dan Layanan Khusus pada tahun 2013 sebanyak 31033 satuan pendidikan dari berbagai jenjang di Indonesia menyelenggarakan pendidikan inklusif dan jumlah tersebut akan bertambah seiring berjalannya waktu.

Permendiknas No 70 Tahun 2009 Tentang Pendidikan Inklusif Bagi Peserta Didik Yang Memiliki Kelainan Dan Memiliki Potensi Kecerdasan Dan/Atau Bakat Istimewa menyebutkan bahwa tujuan dari pendidikan inklusif adalah: 1) Memberikan kesempatan yang seluasluasnya kepada semua peserta didik yang memiliki kelainan fisik, emosional, mental, dan sosial atau memiliki potensi kecerdasan dan/atau bakat istimewa untuk memperoleh Pendidikan yang bermutu sesuai dengan kebutuhan dan kemampuannya. 2) Mewujudkan penyelenggaraan pendidikan yang menghargai keanekaragaman, dan tidak diskriminatif bagi semua peserta didik berkebutuhan khusus. 3) Tujuan dari diselenggarakan pendidikan inklusif adalah untuk memberikan hak pendidikan kepada seluruh anak dan menciptakan pendidikan yang ramah bagi seluruh anak tidak terkecuali. Menyediakan pendidikan yang berkualitas, untuk menggali potensi setiap anak sesuai dengan kebutuhan dan kemampuan anak

Pendidikan inklusif dipandang baik karena selain memanusiakan manusia pendidikan inklusif yang diterapkan di Indonesia diharapkan mampu memeratakan pendidikan bagi PDBK di mana ABK tidak harus ke SLB untuk mendapatkan layanan pendidikan dikarenakan jumlah SLB tidak sebanyak sekolah reguler, sehingga PDBK dapat mencari sekolah terdekat dan mudah diakses oleh $\mathrm{ABK}$, maka pemerataan pendidikan dan layanan pendidikan bagi seluruh anak Indonesia dapat terpenuhi. Pendidikan inklusif juga sebagai salah satu bentuk perwujudan dari Peraturan Menteri Negara Pemberdayaan Perempuan dan Perlindungan Anak Nomor 11 Tahun 2011 tentang Kebijakan Pengembangan Kabupaten/Kota Layak Anak yang memastikan setiap anak mendapatkan akses pendidikan dan pelatihan yang berkualitas tanpa diskriminasi.

Dampak positif dari diselenggarakannya pendidikan inklusif yaitu mampu membuat PDBK lebih merasa di terima di masyarakat dan dihargai, tidak hanya itu, peserta didik reguler pun saat memiliki teman atau lingkungan sosial yang terdapat ABK, mereka belajar bagaimana bersikap toleransi dan menghargai serta menolong teman yang memiliki keterbatasan (McMurray \& Thompson, 2016). Banyak dampak positif dari diselenggarakannya pendidikan inklusif inilah yang menjadikan sistem pendidikan inklusif baik untuk dilaksanakan (Bakken \& Obiakor, 2016). Giangreco (1997) juga menyebutkan dampak yang ditimbulkan pada penyelenggaraan pendidikan inklusif. Dampak pada siswa disabilitas yaitu, program pendidikan lebih relevan dan terfokus, peningkatan akses ke lingkungan yang khas (misalnya, sekolah, komunitas, pekerjaan), akses ke pengalaman/peluang baru di sekolah dan di luar sekolah, akses ke model sejawat, hubungan dan persahabatan baru, meningkatkan harapan, peningkatan kesadaran dan responsif terhadap aktivitas lingkungan masyarakat, peningkatan akuisisi keterampilan. Sedangkan dampak pada siswa reguler adalah, peningkatan apresiasi keragaman manusia, peningkatan respons terhadap kebutuhan orang lain, dengan dan tanpa cacat, meningkatkan kenyamanan berinteraksi dengan penyandang cacat, hubungan dan persahabatan baru, pertumbuhan 
sosial/emosional, tidak mengganggu kualitas pendidikan mereka (misalnya, prestasi akademik), memberikan peluang untuk memecahkan masalah kehidupan nyata, mengembangkan etika/nilai-nilai kepedulian dan komitmen kepada orang lain, tercermin dengan cara yang mengarah pada pertumbuhan pribadi.

Pendidikan Inklusif pada dasarnya merupakan jiwa dari bangsa Indonesia yang sejak sejak awal kemerdekaan, mengusung falsafah Bhineka Tunggal Ika menjadikan Indonesia sebagai suatu bangsa yang memiliki keragaman namun tetap bersatu, tidak terkecuali dalam pendidikan. Keberagaman latar belakang, kondisi fisik, kondisi ekonomi, geografis dan lain sebagainya, tidak menghalangi seorang anak untuk mendapatkan layanan pendidikan (Garnida, 2015).

Pelaksaan pendidikan inklusif tidaklah mulus, masih memiliki kendala Bourke (2010) mengemukakan bahwa kebijakan, prosedur dan struktur yang kurang mendukung untuk mengembangkan pendidikan inklusif menjadi kendala dan membuat pelaksanaan pendidikan inklusif menjadi kurang terarah serta membuat guru dan praktisi frustasi. Rose dkk. (2012) menyebutkan kendala dari sisi kurikulum di mana penerapan PPI tanpa kebijakan dari pusat yang jelas dapat mengakibatkan ketidak konsistenan dalam pengembangan PPI dan penggunaannya, dengan demikian kebijakan mengenai pengembangan PPI diperlukan agar terjadi pemahaman yang seragam sehingga pelaksanannya terarah dan konsisten. McCabe (2003) juga menyebutkan salah satu kendala saat awal pelaksanaan pendidikan inklusif dimana guru pendidikan umum khawatir bahwa menerima siswa penyandang cacat akan mengganggu pencapaian yang siswa lain. Upaya yang dilakukan adalah memberikan kesempatan peningkatan pemahaman dan kompetensi melalui pelatihan pendidikan khusus dan menggunakan sekolah-sekolah pendidikan khusus sebagai pusat sumber untuk guru kelas inklusif, sehingga guru dapat belajar bagaimana mengajar siswa ABK.

$\begin{aligned} & \text { Stubbs } \\ & \text { merangkum } \\ & \text { berikut. }\end{aligned}$
dalam

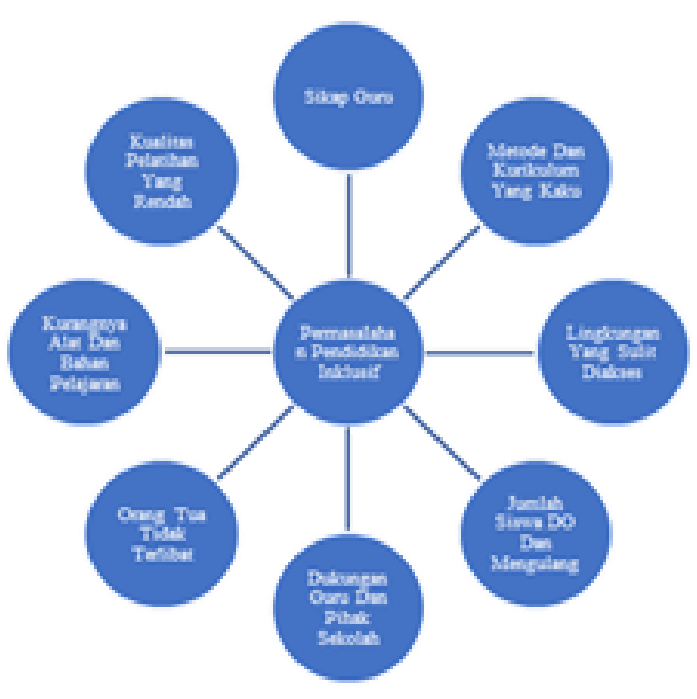

Gambar 1. Masalah sistem pendidikan inklusif

Kendala pada pendidikan inklusif tidak hanya berbicara mengenai salah satu aspek saja, namun merupakan suatu sistem yang saling mendukung satu dengan lain di setiap komponennya. Melalui berbagai kendala yang telah disebutkan, dapat disimpulkan bahwa terdapat kendala baik internal maupun eksternal yang mempengaruhi pelaksanaan pendidikan inklusif. seperti masalah kebijakan, dukungan lingkungan atau support sistem, serta penerimaan dan kompetensi guru akan pendidikan inklusif.

Hasil diskusi peneliti dengan pejabat di Direktorat Pembinaan PKLK, pengawas dinas pendidikan kota Bandung, Kepala Sekolah dan guru pelaksana pendidikan inklusif, Lembaga Sosial Masyarakat yang bergerak dalam bidang Pendidikan Inklusif menyampaikan beberapa kendala yang seringkali dialami oleh sekolah baik yang menyelenggarakan pendidikan inklusif maupun yang belum atau sedang menuju pendidikan inklusif. Beberapa kendala yang seringkali dihadapi, seperti kurangnya pemahaman dari pendidik dan masyarakat mengenai pendidikan inklusif sehingga membuat pendidikan inklusif 
berjalan kurang baik dan dapat menimbulkan penolakan. Faktor dana turut menjadi kendala bagi sekolah, dikarenakan dana untuk menyediakan layanan pendidikan bagi peserta didik berkebutuhan khusus tidaklah sedikit. Kendala kompetensi pendidik turut serta mempengaruhi dalam mengembangkan modifikasi kurikulum serta melaksanakan pembelajaran dan evaluasi hasil belajar. Pendidik yang tidak siap dan kurang menerima sistem pendidikan inklusif, seringkali merasa terbeban karena harus mengakomodir dan mengelola kelas dengan keberagaman peserta didik yang sangat jauh kemampuannya, dan juga tidak semua guru mampu mengatasi berbagai hambatan yang dimiliki peserta didik. Keterampilan dan kemampuan untuk mengembangkan kurikulum bagi PDBK pun turut serta menjadi kendala dalam pendidikan inklusif, karena masih ditemukan pendidik yang merasa terbeban dan keberatan untuk memodifikasi kurikulum atau mengembangkan program pembelajaran individual (PPI) bagi PDBK, dapat juga dikarenakan ketidaktahuan pendidik untuk mengembangkan PPI atau kurikulum yang dapat mengakomodasi seluruh kebutuhan peserta didik.

Kurikulum sebagai salah satu komponen utama dalam pendidikan menjadi salah satu aspek yang masih memiliki kendala dalam implementasinya, terutama pada implementasi kurikulum pada sekolah penyelenggara pendidian inklusif, dimana memiliki ciri khas tersendiri bagi kelas inklusif.

Seperti yang dikemukan oleh Taba (1962) bahwa kurikulum dianggap sebagai a plan of learning yang artinya kurikulum merupakan suatu rencana yang berisikan rencana-rencana pembelajaran, atau belajar yang disengaja atau direncanakan. Senada dengan hal tersebut Zais (1976:8) menyebutkan "curriculum as a blueprint for education, consist ultimately of experiences that it planned for learner to have". Kurikulum sebagai cetak biru pendidikan, menjadikan kurikulum sebagai suatu pedoman yang berisikan arah dan tujuan dari pendidikan, dapat diasumsikan sebagai pendidikan secara luas atau nasional, maupun pendidikan anak secara individual dan berisikan pengalamanpengalaman belajar yang telah direncanakan supaya dimiliki oleh peserta didik. Pengertian kurikulum di Indonesia tertuang dalam Undang Undang No. 20 Pasal 1 Ayat 19 Tahun 2003 Tentang Sistem Pendidikan Nasional yang menyatakan bahwa "Kurikulum merupakan seperangkat rencana dan pengaturan mengenai tujuan, isi, dan bahan pelajaran, serta cara yang digunakan sebagai pedoman penyelenggaraan kegiatan pembelajaran untuk mencapai tujuan pendidikan tertentu". Melalui definisi tersebut kurikulum diartikan sebagai perangkat rencana berisikan komponen kurikulum yang dituangkan ke dalam dokumen pembelajaran dengan disusun secara sistematis dan sistemik untuk memberikan pengalaman belajar agar tercapainya tujuan pendidikan, dan dokumen tertulis tersebut digunakan sebagai acuan dalam implementasi pembelajaran sampai pada pelaksanaan di kelas.

Mengembangkan suatu kurikulum memerlukan banyak pertimbangan karena kurikulum sebagai rancangan yang berisikan arah serta tujuan pendidikan dan juga menjadi pedoman pelaksanaan pendidikan, maka untuk mengembangkan suatu kurikulum dibutuhkan landasan atau fondasi yang tepat supaya kurikulum yang dikembangkan dapat digunakan dan relevan dengan jamannya dan dimana kurikulum itu diterapkan. Berbagai perbedaan karakteristik baik geografi, budaya, lingkungan, sumber daya, dan lain sebagainya dapat mempengaruhi pengembangan dan penerapan kurikulum di setiap negara bahkan di setiap satuan pendidikan. Landasan pengembangan kurikulum yang dikemukan oleh para ahli, dapat digeneralkan ke dalam empat pokok landasan utama yang menjadi landasan pengembangan kurikulum di Indonesia yaitu landasan filosofis, psikologis, sosial budaya, dan yuridis. 
Kurikulum yang dikembangkan sesuai dengan landasannya yang tepat, menjadikan kurikulum tersebut relevan, namun tidak hanya landasan kurikulum saja yang menjadikan kurikulum tersebut relevan, suatu kurikulum harus memenuhi prinsip-prinsip pengembangan kurikulum agar kurikulum tersebut dapat digunakan atau diimplementasikan. Sanjaya (2008) menyebutkan bahwa dalam mengembangkan suatu kurikulum harus mengikuti prinsip-prinsip relevansi, fleksibilitas, kontinuitas, efektifitas, dan efisien. Kurikulum yang tidak memiliki landasan atau fondasi yang ajeg akan mudah berubah dan tidak relevan untuk diterapkan dari waktu kewaktu, sedangkan kurikulum yang tidak memenuhi prinsip pengembangan kurikum akan sulit untuk dilaksanakan dilapangan.

Kurikulum tidak sekedar rancangan berupa dokumen tertulis, namun diimplementasikan pada satuan pendidikan. Sebaik apapun desain ataupun rancangan kurikulum apabila tidak diterapkan maka kurikulum hanyalah sebagai dokumen pasif yang tidak memiliki kekuatan dan tidak akan merubah serta tidak memiliki dampak apapun, dengan demikian kurikulum berupa rancangan haruslah diterapkan atau dilaksanakan (Wahyudin, 2014). Oliva \& Gordon (2013:19) menyatakan "Curriculum implementation is defined as the translation of plans into action", dengan jelas pernyataan tersebut menyatakan bahwa implementasi kurikulum merupakan suatu tindakan yang didasarkan dari perencanaan yang telah dibuat. Rencana yang dilaksanakan menjadi penekanan pada makna implementasi. Implementasi kurikulum dapat diartikan sebagai pembelajaran, dimana kurikulum yang telah dirancang dapat dilaksanakan pada satuan terkecil yaitu di ruang kelas (Miller \& Seller, 1985; Rusman, 2012). Pengaplikasian rencana yang tercantum dalam RPP dilaksanakan melalui serangkaian aktivitas pembelajaran yang memberikan pengalaman siswa untuk belajar. Hamalik (2013) menyatakan implementasi kurikulum adalah penerapan atau pelaksanaan program kurikulum yang telah dikembangkan dalam tahap sebelumnya, kemudian diujicobakan dengan pelaksanaan dan pengelolaan, sambil senantiasa dilakukan penyesuaian terhadap situasi lapangan dan karakteristik peserta didik, baik perkembangan intelektual, emosional, serta fisiknya. Seperti yang tertuang pada dokumen RPP, dimana dalam pengembangan RPP guru melakukan analisis terlebih dahulu dan penyusunan metodemetode pembelajaran yang akan diterapkan kedalam RPP. Hal-hal pokok yang dilihat dalam suatu implementasi kurikulum menurut Hamalik (2013) adalah, 1) Pengembangan program, mencakup program tahunan, program semester, bulanan, mingguan dan harian. Ada juga program bimbingan dan konseling atau remedial. 2) Pelaksanaan pembelajaran, proses interaksi antara peserta didik dengan lingkungannya. Dalam konteks kurikulum mengambil dari RPP adalah kegiatan pendahuluan, inti dan penutup. 3) Evaluasi, kegiatan yang dilakukan sepanjang proses pelaksanaan kurikulum. Ketiga hal tersebut menjelaskan bahwa implementasi kurikulum tidak hanya melihat pelaksanaannya saja, namun juga melihat dari perencanaan yang dikembangkan, karena perencanaan yang telah dikembangkan menjadi pedoman atau acuan bagi pelaksanaan kurikulum agar sesuai dengan arah dan tujuan yang telah ditentukan dan evaluasi menjadi salah satu indikator keberhasilan pencapaian tujuan maupun sebagai dasar perbaikan rancangan maupun pelaksanaan.

Pelaksanaan kurikulum terlebih dahulu didasari pada penerimaan kurikulum dan keterpahaman akan pendidikan inklusif. Faktor dominan yang dapat mempengaruhi kelancaran implementasi kurikulum menurut Jackson dalam Wahyudin (2014) mengatakan terdapat 5 faktor yang menjadi penyebab terhambatnya implementasi kurikulum yaitu, guru yang tidak inovatif, guru tidak memiliki keterampilan dan pengetahuan terhadap hal-hal baru, tidak tersedia sarana, ketidakcocokan kebijakan dengan inovasi, tidak adanya motivasi bagi pelaksana inovasi. Sedangan 
Syaodih dalam Rusman (2012) mengatakan bahwa sebaik apapun rancangan atau desain yang telah disusun, tetap saja keberhasilan pelaksanaan kurikulum sangat bergantung kepada guru sebagai ujung tombak pendidikan. Pelaksanaan kurikulum dapat terjadi karena peran serta guru yang sangat besar, dengan demikian kurikulum yang dikembangkan harus mempertimbangkan guru sebagai pemeran utama dalam implementasi kurikulum dengan didukung oleh sistem yang tepat. Fullan dalam Orstein dan Hunkins (2013) mengatakan bahwa faktor yang mempengaruhi adalah pemahaman dari implementator terkait karakteristik perubahan yang akan dilakukan. Kurangnya pemahaman tentang informasi atau karakteristik kurikulum oleh implementator dapat menyebabkan kegagalan implementasi. Oleh karenanya penting untuk melakukan sosialisasi atau diseminasi kepada seluruh elemen atau warga sekolah yang terkena dampak perubahan kurikulum tersebut sehingga mereka memiliki informasi yang cukup untuk dapat menerima terjadinya perubahan di lingkungannya.

Kurikulum yang digunakan pada sekolah reguler adalah kurikulum 2013 tidak terkecuali bagi sekolah penyelenggara pendidikan inklusif seperti yang disampaikan oleh Mudjito dkk. (2014) kurikulum yang digunakan pada kelas inklusif pada dasarnya adalah menggunakan kurikulum pada kurikulum sekolah umum, namun bagi peserta didik berkebutuhan khusus, kurikulum yang ada perlu di sesuaikan atau dimodifikasi mengikuti kemampuan peserta didik berkebutuhan khusus. Kelas inklusif memiliki ciri khas keberagaman yang sangat dominan, dengan demikian prinsip fleksibilitas kurikulum akan terlihat. Kurikulum pada sekolah penyelenggara pendidikan inklusif adalah kurikulum yang adaptif atau fleksibel untuk dapat disesuikan dengan kebutuhan PDBK. Pemahaman adaptif dan modifikasi dalam pendidikan atau kurikulum seperti disampaikan oleh Valentin (2007:133) menyatakan "adaption are things used to help a student better engage in her or his environment and surroundings, while modifications are changes made to enhance the curriculumboth are used to help the student process information and learn", hal senada dikemukakan juga oleh Friend dan Bursuck (2015) menyebutkan bahwa sifat pembelajaran yang akomodatif dan modifikatif merupakan hak bagi PDBK memperoleh pendidikan yang sesuai dengan kemampuan dan kebutuhan mereka. Kurikulum yang akomodatif adalah kurikulum yang mampu menyesuaikan dengan kemampuan PDBK, contohnya adalah PDBK mengikuti pembelajaran yang sama di kelas reguler serta menerima materi yang sama, namun pada saat melakukan pengerjaan soal bagi PDBK jumlah soal dikurangi atau mengurangi kedalaman maupun keluasan suatu materi dikarenakan memiliki hambatan kecerdasan. Sedangkan pembelajaran yang dimodifikasi suatu pembelajara yang diubah sesuai dengan kemampuan dan kebutuhan peserta didik seperti suatu materi dihilangkan karena PDBK memiliki hambatan pendengaran yang tidak memungkinkan untuk mempelajari materi tersebut.

Terdapat 5 model dari kurikulum adaptif yang disimpulkan oleh beberapa ahli (Mitchell, 2010; Pedoman Umum Penyelenggaraan Pendidikan Inklusif, 2013; Visen, 2018) yaitu, 1) Model eskalasi, kurikulum bagi PDBK yang dinaikkan dari standar kurikulum reguler diperuntukan bagi siswa CIBI (Cerdas Instimewa dan atau Bakat Istimewa). 2) Model duplikasi: kurikulum bagi PDBK sama seperti yang digunakan pada kurikulum reguler. 3) Model modifikasi: kurikulum bagi PDBK dinaikkan atau direndahkan, disesuaikan dengan kebutuhan PDBK. 4) Model substitusi: beberapa bagian kurikulum diganti dengan yang kurang lebih setara. 5) Model omisi: beberapa bagian kurikulum ditiadakan karena tidak memungkinkan untuk dilakukan oleh PDBK

Pelaksanaan atau implementasi kurikulum diartikan sebagai pembelajaran, 
Gagne \& Briggs (1979:3) mengemukakan "instruction is a human undertaking whose purpose is to help people learn...is a set of events which affect learners in such a way that learning is facilitated". Pernyataan tersebut senada dengan Smaldino dkk. (2005:7) yang menyatakan "Instruction is the arrangement of information and the environment to facilitate learning. This may be done by the learner or the instructor". Melalui kedua konsep pembelajaran yang disampaikan oleh kedua ahli tersebut dapat disimpulkan bahwa pembelajaran adalah suatu kegiatan/aktivitas yang direncanakan dan disengaja dengan tujuan membuat peserta didik belajar. Kegiatan yang direncanakan tersebut terdiri dari berbagai informasi, metode, lingkungan yang disusun sedemikian rupa agar tercipta lingkungan yang mendukung terjadinya belajar pada peserta didik.

Pendekatan pembelajaran yang berlaku bagi Pendidikan Dasar di Indonesia sesuai dengan Permendikbud No 22 Tahun 2016 Tentang Standar Proses Pendidikan Dasar dan Menengah yang menyatakan bahwa satuan pendidikan dasar kelas I-VI menggunakan pendekatan saintifik (saintific approach) dan pendekatan tematik terpadu agar pembelajaran lebih bermakna dan mudah dipahami oleh siswa (Rusman, 2015). Dengan demikian pelaksanaan pembelajaran bagi siswa SD tidak terpisah antar mata pelajaran namun disatukan oleh tema. Pembelajaran yang dilaksanakan di kelas inklusif sesuai dengan peraturan yang berlaku menggunakan kurikulum 2013. Namun terdapat beberapa bagian yang memungkinkan untuk dimodifikasi sesuai dengan kemampuan dan kebutuhan peserta didik. Pembelajaran memiliki 5 komponen yaitu tujuan, bahan/materi, strategi, media dan evaluasi pembelajaran yang saling terintegrasi (Rusman, 2015).

Desain kurikulum bagi PDBK harus memperhatikan kebutuhan dan karakteristik PDBK dengan mengembangkan Program Pembelajaran Individual (PPI) untuk mengakomodasi kebutuhan PDBK (Garnida, 2015; Richards \& Dooley, 2015). Istilah PPI diambil dari Individualize
Education Programe (IEP). Valentin (2007:131) menyebutkan "Individualized Education Program (IEP) is a legal document that outlines the spesific learning needs of the student and consequent adaptations to the curriculum and physical environment that must be made to accomodate the child".

PPI memuat enam komponen (Merce \& Mercer, 1989) yaitu, 1) Taraf kemampuan siswa saat ini memberikan gambaran dari kemampuan peserta didik seperti karakteritsik peserta didik, hambatan yang dimiliki, tingkat kecerdasan, potensi dan kepribadiannya sebagai dasar guru untuk menentukan pelayanan pembelajaran yang tepat dalam mengakomodir kebutuhan peserta didik. Identifikasi didapat dari hasil analisis assement terhadap peserta didik yang dilakukan sebelum, dengan mengetahui sejauh mana kemampuan peserta didik maka dapat dipertimbangkan materi, prosedur, metode, teknik, dan alat bantu pelajaran yang sesuai. 2) Tujuan umum yang akan dicapai (annual goal), sebuah pernyataan mengenai tujuan atau hasil akhir yang diharapkan dapat dimiliki peserta didik setelah mengikuti pembelajaran. Tujuan umum ini menjelaskan tentang kompetensi dan kemampuan baik kognitif, afektif dan psikomotor peserta didik. Pengembangan tujuan umum tetap bertolak kepada hasil assement dan taraf kemampuan dan kebutuhan peserta didik supaya tujuan dapat dicapai. 3) Tujuan pembelajaran khusus (short-term objectives), merupakan beberapa pernyata-an yang lebih rinci untuk mencapai tujuan umum. Pernyataan tersebut menjelaskan tujuan pada setiap unit atau tema yang dijabarkan dengan rumusan yang operasional, khusus, dapat diamati, dan dapat diukur serta menunjukkan perubahan perilaku. 4) Deskripsi tentang pelayanan pembelajaran, yaitu gambaran tentang layanan pembelajaran yang akan diberikan kepada peserta didik, dinyatakan dalam dokumen pembelajaran yang meliputi, materi yang diberikan, prosedur strategi/metode yang digunakan untuk 
menyampaikan materi, dan media/alat bantu pengajaran yang akan digunakan untuk mempermudah pemahaman pengajaran. Melalui gambaran tersebut baik guru maupun orang tua peserta didik dapat memahami seperti apa layanan pembelajaran yang akan diberikan dan sesuai dengan kemampuan serta kebutuhan peserta didik mengacu kepada komponen sebelumnya. 5) Waktu dimulainya kegiatan dan lamanya diberikan, alokasi waktu merupakan rincian tentang berapa lama peserta didik untuk dapat mencapai tujuan umum yang telah ditetapkan, yang kemudian dirinci menjadi lama waktu yang dibutuhkan untuk mempelajari suatu materi atau memberikan pelayanan pembelajaran. 6) Evaluasi, untuk menilai apakah tujuan telah tercapai dan sejauh mana perubahan kognitif, afektif dan psikomor yang telah dimiliki peserta didik. Evaluasi dilakukan dengan menggunakan berbagai macam teknik dan instrumen yang tepat. Penilaian autentik digunakan pada evaluasi peserta didik untuk melihat kemampuan peserta didik secara menyeluruh.

Kitano dan Kirby dalam Abdurrahman (2012) menyebutkan lima langkah dalam merancang PPI yaitu, membentuk tim PPI, menilai kebutuhan anak, mengembangkan tujuan jangka panjang dan tujuan jangka pendek, merancang metode dan prosedur pencapaian tujuan, menentukan metode evaluasi untuk melihat kemajuan anak. Setiap langkah tidaklah mudah dilakukan, guru harus mampu untuk berkolaborasi dengan pihak terkait dan juga memiliki kompetensi dalam mengembangkan PPI. Kompetensi guru menjadi hal yang penting dalam merancang, melaksanakan dan mengevaluasi PPI didasari oleh pemahaman akan pendidikan inklusif terlebih dahulu (Walker, 2016; Rahmawati, 2014).

Berdasarkan pada data dan penjelasan di atas, maka pada penelitian ini secara umum rumusan masalah adalah untuk mengetahui bagaimakah implementasi kurikulum pada sekolah penyelenggara pendidikan inklusif di kota Bandung. Lebih rinci rumusan masalah yang ada adalah tentang 1) bagaimana perencanaan pembelajaran pada sekolah penyelenggaraan pendidikan inklusif?, 2) bagaimana peleksanaan pembelajaran pada sekolah penyelenggara pendidikan inklusif?, 3) bagaimanakah evaluasi pembelajaran pada kelas inklusif?, 4) apa saja faktor penghambat dan pendukung pelaksanaan pendidikan inklusif?. Dari ke empat rumusan masalah khhusus tersebut akan dibahas satu persatu.

\section{METODE}

Metode penelitian menggunakan pendekatan kualitatif yang merujuk pada tujuan penelitian dan sifat penelitian yang menekankan pada proses serta melihat aktivitas yang terjadi dilapangan secara natural atau dengan latar belakang alami (Moleong, 2017), sehingga data yang diperoleh merupakan data deskriptif untuk menjelaskan suatu fenomena atau kejadian yang bersifat alami sesuai dengan kondisi yang ada tanpa dipengaruhi apapun. Format deskriptif bertujuan untuk menjelaskan, meringkas berbagai kondisi, berbagai situasi, atau berbagai variabel yang timbul di masyarakat yang menjadi objek penelitian ini berdasarkan apa yang terjadi (Bungin, 2013). Teknik pengumpulan data dengan wawancara, observasi dan studi dokumentasi, dengan menggunakan instrumen pedoman wawancara, catatan lapangan dan daftar cek. Dengan menggunakan 2 sekolah sebagai objek penelitian, dan disetiap sekolah responden terdiri dari unsur kepala sekolah, guru, dan GPK. Validasi data menggunakan triangulasi sumber data dimana pernyataan kepala sekolah, guru dan orang tua murid saling mengkonfirmasi satu dengan yang lain dan triangulasi metode, dalam pengumpulan data menggunakan metode yang berbeda yaitu wawancara, observasi dan dokumentasi (Ali \& Asrori, 2014).

\section{HASIL DAN PEMBAHASAN Hasil}

Implementasi kurikulum terdiri dari tiga tahapan yaitu perencanaan, pelaksanaan, dan evaluasi. Perencanaan pem- 
belajaran terkait dengan dokumentasi kurikulum seperti prota, promes, silabus dan RPP, kemudian pada tahap pelaksanaan bagaimana guru mengimplementasikan perencanaan pembelajaran, dan pada tahap evaluasi melihat evaluasi hasil belajar yang dilakukan.

Perencanaan, pada sekolah pertama guru kelas melakukan perencanaan pembelajaran bagi peserta didik reguler, dikarenakan sekolah baru memiliki GPK sehingga masih dalam tahap orientasi, maka belum dikembangkannya PPI bagi PDBK. Guru kelas belum melakukan penyelarasan kurikulum bagi PDBK dikarenakan keterbatasan waktu dan jumlah PDBK yang cukup banyak pada sekolah tersebut, ratarata di setiap kelas terdapat 8-15 orang PDBK dari 20-30 peserta didik dalam satu kelas. bagi PDBK perencanaan pembelajaran menjadi kurang relevan karena mengacu pada perencanaan pembelajaran reguler.

Pada sekolah kedua guru kelas melakukan perencanaan kurikulum dengan mengembangkan dokumen prota, promes, silabus dan RPP bagi peserta didik reguler, sedangkan penyelarasan kurikulum dilakukan oleh GPK dengan berdiskusi kepada guru kelas. Proses penyelarasan kurikulum yang dilakukan adalah diawali dengan identifikasi, dilanjutkan dengan assement peserta didik berkebutuhan khusus, melalui hasil assement GPK menyusun PPI, terakhir PPI tersebut didiskusikan dengan guru kelas, orang tua dan kepala sekolah. Melalui penyelarasan kurikulum didapati komponen kurikulum yang dimodifikasi, seperti tujuan, konten, metode dan evaluasi. GPK juga mengembangkan program binadiri bagi PDBK disesuaikan dengan kebutuhan dan kemampuannya. Secara garis besar dokumen perencanaan yang disusun oleh guru dan GPK pada sekolah kedua.
Tabel 1. Dokumentasi kurikulum

\begin{tabular}{llll}
\hline No & Dokumen & Wali Kelas & GPK \\
\hline 1 & Prota & Reguler & PDBK \\
2 & Promes & Reguler & \\
3 & Silabus & Reguler & \\
4 & RPP & Reguler & \\
5 & Assement & & PDBK \\
6 & PPI & & PDBK \\
7 & Evaluasi & Reguler & PDBK \\
\hline
\end{tabular}

Perencanaan pembelajaran yang dilakukan baik bagi peserta didik reguler maupun peserta didik berkebutuhan khusus tetap merujuk standar proses kurikulum nasional, dimana pada sekolah dasar memakai pendekatan tematik. Seluruh materi pada setiap mata pelajaran disatukan oleh satu tema yang telah ditentukan. Sedangkan strategi yang digunakan dengan menggunakan pendekatan saintifik. Model pembelajaran yang digunakan adalah model pembelajaran berbasis masalah (problem based learning), model pembelajaran berbasis proyek (project based learning), dan model inquiry/discovery learning.

Pelaksanaan, pada aspek ini sekolah pertama pelaksanaan pembelajaran di kelas mengacu pada RPP, namun terdapat perbedaan. RPP yang disusun tidak mencantumkan pembelajaran bagi PDBK di kelas, sedangkan faktanya guru melaksanakan penyesuaian materi dan evaluasi bagi PDBK. Kegiatan Pembelajaran di kelas melibatkan seluruh peserta didik, pada kegiatan pendahuluan guru melakukan motivasi untuk mempersiapkan kesiapan anak menerima pembelajaran, lalu wali kelas membahas materi dengan menanyakan kembali materi sebelumnya dan beberapa anak reguler maupun PDBK menjawab pertanyaan tersebut. Kegiatan inti pembelajaran, guru kelas mengawali dengan menjelaskan materi seluruh peserta didik memperhatikan, kemudian setelah selesai memberikan penjelasan dilanjutkan dengan soal latihan, saat peserta didik reguler mengerjakan soal latihan, guru kelas mendatangi PDBK untuk kembali menjelaskan materi yang telah diberikan disesuaikan dengan kemampuan PDBK, dengan menyederhanakan materi dan 
bahasanya. Metode yang digunakan adalah ceramah, sedangkan media yang digunakan adalah buku teks pelajaran. Pada kegiatan penutup, guru mengulas tentang materi hari ini dengan mengajukan tanya jawab, memberikan pertanyaan yang juga dapat dijawab oleh PDBK.

Di sekolah kedua, pelaksanaan pembelajaran mengikuti dokumen perencanaan yang telah disusun dalam RPP dan PPI bagi PDBK. Pembelajaran di kelas sebisa mungkin untuk melibatkan seluruh peserta didik. Pada kegiatan pendahuluan seluruh peserta didik harus memperhatikan guru kelas. guru kelas memberikan pengutan baik literasi, karakter, keagamaan dan penguatan kebiasaan. Kemudian guru kelas mengulas materi sebelumnya dengan melakukan tanya jawab kepada peserta didik. setelah itu saat masuk kepada kegiatan inti, PDBK yang mendapatkan perbedaan materi akan dibimbing oleh GPK. Pada saat-saat tertentu, tugas atau kegiatan pembelajaran yang berkelompok, akan memasukkan PDBK kedalam kelompok. Metode yang digunakan adalah ceramah, dan media yang digunakan sebagain besar adalah buku teks pelajaran. PDBK juga menggunakan buku teks pelajaran yang disesuaikan. Pada kegiatan penutup, guru kelas memberikan penguatan materi dan tugas bagi peserta didik reguler, sedangkan PDBK diberikan oleh GPK. Dengan demikian pelaksanaan pembelajaran di kelas, melibatkan seluruh peserta didik kedalam pembelajaran bersama-sama, namun pada materi dan saat-saat tertentu, PDBK menerima perbedaan materi, dan evaluasi dan media pembelajaran untuk disesuaikan dengan kemampuan masingmasing PDBK

Evaluasi, evaluasi tetap merujuk pada standar proses kurikulum nasional, yaitu penilaian autentik untuk menilai sikap, pengetahuan dan keterampilan. Pada sekolah pertama instrumen evaluasi baik bagi peserta didik reguler maupun PDBK dikembangkan oleh guru kelas, karena sekolah baru memiliki GPK dan sedang dalam masa orientasi. Pada pelaksanaan ujian sekolah, PDBK menerima soal yang berbeda disesuaikan dengan kemampuannya, dan dalam pengerjaan soal guru membantu beberapa PDBK dengan membacakan soal supaya dapat lebih dipahami.

Pada sekolah kedua instrumen evaluasi beserta penilaian dilakukan oleh GPK dengan dilakukan penyesuaian, baik kedalaman soal maupun cara penyampaian soal dengan memperbesar huruf bagi yang low vision, memberikan ruang menulis yang lebih lebar serta gambar pendukung soal. Pada saat pelaksanaan ujian, PDBK yang belum mampu mandiri dalam mengerjakan soal akan dibantu oleh GPK dengan membacakan soal, mendiktekan jawaban, mengarahkan cara menjawab pilihan dan lain sebagainya.

Penyelenggaraan pendidikan inklusif tidak terlepas dari beberapa faktor pendukung dan penghambat. Faktor yang mendukung adalah pemimpin yang terbuka akan masukan dan memiliki visi yang sama untuk memajukan pendidikan inklusif, rekan sejawat yang dapat berkoordinasi dengan baik, SDM yang berkompeten, orang tua yang saling mendukung, kurikulum yang fleksibel, sarana dan prasana yang dapat dimanfaatkan, bantuan dana dari berbagai pihak, kebijakan yang menjadi payung hukum, SMP yang mau menerima PDBK, masyarakat yang terbuka dengan PDBK.

Sedangkan beberapa faktor yang menjadi kendala adalah pelaksana kebijakan merasakan bahwa kebijakan yang ada masih kurang jelas atau belum menyentuh pada tahap teknis. Dana yang masih kurang terutama dana untuk mengembangkan program pendukung kekhususan dan dana untuk merekrut GPK, sehingga menjadi kendala kurangnya SDM. Status kepegawaian guru dan GPK turut menjadi salah satu faktor yang diperhatikan oleh kepala sekolah. Pada lingkungan di sekolah pertama, masih terdapat masyarakat yang belum memahami sekolah inklusif sehingga memberikan label bahwa sekolahnya seperti SLB sehingga masyarakat sekitar takut untuk memasukkan anaknya bersekolah disekolah tersebut. Berikut ta- 
bel tentang faktor pendukung dan faktor penghambat pendidikan inklusif.

Tabel 2. Faktor Pendukung dan Penghambat

\begin{tabular}{|c|l|l|l|}
\hline No & \multicolumn{1}{|c|}{ Aspek } & \multicolumn{1}{c|}{ Pendukung } & \multicolumn{1}{c|}{ Hambatan } \\
\hline 1 & Pemimpin & $\begin{array}{l}\text { Memberikan sosialisasi } \\
\text { pemahaman pendidikan } \\
\text { inklusif }\end{array}$ & \\
\hline & & $\begin{array}{l}\text { Terbuka akan ide untuk } \\
\text { memajukan inklusif } \\
\text { Memberikan } \\
\text { kesempatan pelatihan } \\
\text { bagi guru }\end{array}$ & \\
\hline Membuka kerjasama \\
\end{tabular}

\section{Pembahasan}

\section{Perencanaan Pembelajaran}

Kurikulum yang diterapkan pada sekolah penyelenggara pendidikan khusus tetaplah kurikulum nasional, sesuai dengan Permendiknas No 70 Tahun 2009 Tentang Pendidikan Inklusif Bagi Peserta Didik Yang Memiliki Kelainan Dan Memiliki Potensi Kecerdasan Dan/Atau Bakat Istimewa yang menyebutkan bahwa kurikulum yang digunakan tetap mengacu pada standar kurikulum nasional, namun bagi PDBK yang memiliki hambatan kecerdasan sehingga tidak mampu mengikuti standar kurikulum nasional, maka dapat mengembangkan kurikulum yang mengakomodasi kebutuhan dan kemampuan PDBK dengan dilakukan penyesuaian-penyesuaian. Kurikulum yang akan diimplementasikan terlebih dahulu direncanakan, bagi peserta didik berkebutuhan khusus artinya adalah dilakukan adaptasi atau penyesuaian kurikulum. Guru harus memahami untuk apa kurikulum diadaptasi dan diselaraskan serta bagian mana saja yang dapat diselaraskan (Miller-Day dkk., 2013). Westwood (2001) menyampaikan bahwa untuk mengakomodasi kebutuhan pendidikan bagi PDBK yang berada di sekolah reguler perlu ada perbedaan atau penyesuaian, beberapa aspek yang dapat disesuaikan adalah konten kurikulum, metode pembelajaran, pencapaian yang harus dicapai, dan evaluasi.

Modifikasi kurikulum dilakukan oleh sekolah kedua dengan mengembangakn program tahunan dan PPI bagi PDBK. terkait dengan modifikasi konten bagi PDBK dilakukan dengan menurunkan indikator atau materi dengan menggunakan materi kelas dibawahnya, sedangkan sekolah pertama tidak mengembangkan PPI untuk PDBK. Penyesuaian konten dilakukan atas dasar hasil assement akademik PDBK dan didiskusikan kepada orang tua dan wali kelas, apa saja materi yang dapat disamakan dengan materi kelas dan materi apa saja yang dapat dihilangkan, diubah, diturunkan maupun digantikan dengan materi yang lain. dengan demikian GPK dan wali kelas melakukan penyelarasan materi bagi PDBK. Metode pembelajaran di kelas tetap mengacu pada reguler, sedangkan bagi PDBK dibimbing oleh GPK. GPK yang mengajarkan dengan pendekatan sesuai pada buku teks kurikulum 2013 sehingga pendekatan tematik dan saintifik tetap dilaksanakan oleh GPK. Bagi PDBK pencapaian pembelajaran tidak difokuskan pada akademik, namun lebih kepada aspek sosial, keterampilan dan pengembangan bakat atau potensi PDBK, dengan demikian pada sekolah kedua GPK bertugas untuk merancang program bina diri untuk 
mengembangkan kemandirian dan potensi PDBK.

Aspek evaluasi hasil belajar bagi PDBK dilakukan modifikasi seperti menyesuaikan jumlah soal atau tingkat kesulitan soal dengan materi yang telah dikuasainya. penulisan soal pun dibedakan seperti untuk PDBK yang memiliki hambatan penglihatan (low vision) maka besar huruf pada soal diperbesar.

Perencanaan modifikasi kurikulum dapat diketahui melalui dokumen perencanaan kurikulum yang dikembangkan oleh guru maupun GPK. Dari kedua sekolah diketahui bahwa guru kelas mengembangakan dokumen kurikulum yang ditujukan bagi reguler terlebih dahulu. Penyusunan prota, promes, silabus dan RPP tetap mengacu kepada materi reguler dan guru mempertimbangkan mayoritas peserta didik di kelas dalam pengembangan perencanaan kurikulum. Sekolah kedua yang memiliki GPK, mengembangkan perencanaan akademik bagi PDBK. Tim GPK dibentuk oleh kepala sekolah untuk membuat program bagi PDBK, dengan membuat program tahunan bagi PDBK secara general kemudian langsung dikembangkan PPI bagi PDBK. Penyusunan PPI dilakukan berdasarkan hasil assement yang didapat dari psikolog, maupun assesment yang dilakukan disekolah oleh tim GPK. Guru kelas dan orang tua turut serta dilibatkan dalam penyusunan PPI untuk mendapatkan program yang tepat bagi PDBK meskipun porsi wali kelas tidak terlalu banyak dalam pengembangan PPI. Sedangkan bagi sekolah pertama dikarenakan kapasitas SDM untuk mengembangkan PPI belum ada, maka tidak mengembangkan dokumen tersebut.

PPI merupakan program bagi PDBK yang mempertemukan kebutuhan khas PDBK dengan kurikulum disekolah, dimana tujuannya adalah untuk mengakomodasi PDBK dalam pembelajaran di sekolah (Abdurrahman, 2012; Valentin, 2007). Abdurrahman (2012), dan Merce \& Mercer (1989) menyebutkan komponen PPI adalah, taraf kemampuan siswa saat ini, tujuan umum yang akan dicapai (tahunan), tujuan pembelajaran khusus, deskripsi pelayanan pembelajaran, waktu dimulai kegiatan dan lama waktu yang diberikan, dan evaluasi. Komponen waktu belum dimasukkan kedalam PPI yang dikembangkan oleh sekolah disebabkan PDBK tidak ditargetnya atau difokuskan kepada akademik namun kepada kemandiriannya.

Pengembangan kurikulum bagi reguler dan PDBK dipisahkan namun tetap dikoordinasikan antara wali kelas, GPK, orang tua murid dan kepala sekolah. GPK sebagai tim pengembang kurikulum merasa bahwa pengembangan kurikulum bagi PDBK masih belum ajeg secara format maupun laporan pertanggungjawabannya. Laporan secara dokumentasi tidak ditagihkan oleh pengawas maupun dinas setempat, sehingga menyebabkan format maupun laporan dokumentasi kurikulum akan disesuaikan dengan SDM yang terdapat pada sekolah tersebut tanpa ada format atau keharusan dokumen apa saja yang perlu untuk disusun menyebabkan juga bagi sekolah yang tidak mengembangkan modifikasi kurikulum bagi PDBK tidak merasa menjadi suatu keharusan.

\section{Pelaksanaan Pembelajaran}

Pelaksanaan pembelajaran yang dilakukan di kelas inklusif memiliki keunikan dengan keberadaan PDBK dan kurikulum yang berbeda antara PDBK dan reguler. Pelaksanaan pembelajaran di kelas tetap melibatkan seluruh peserta didik, diusahakan seluruh peserta didik terlibat di dalamnya dan tidak ada perbedaan, namun tetap terdapat penyesuaian bagi PDBK. Berikut beberapa modifikasi yang dilakukan oleh sekolah saat pelaksanaan pembelajaran dilihat dari beberapa aspek.

Materi Pembelajaran, Westewood (2001) menyatakan bahwa materi bagi PDBK berebda dengan peserta didik reguler dengan melakukan penyesuaian kemampuan baik bagi peserta didik yang memiliki hambatan maupun peserta didik CIBI. Pada sekolah pertama materi pembelajaran yang diberikan kepada PDBK adalah materi dengan topik atau tema yang sama namun disederhanakan, sedangkan bagi sekolah kedua materi yang diberikan dapat sama dengan teman sekelasnya namun dapat juga menggunakan 
materi yang jauh dibawah teman-teman sekelasnya. Modifikasi materi dilakukan dengan melihat pada kemampuan akademik PDBK, guru kelas melakukan assesmen kemampuan kognitif PDBK, sejauh mana materi yang dapat diterimanya. Bagi sekolah pertama guru kelas melakukan pencatatan kedalaman materi yang mampu dituntaskan oleh PDBK kedalam jurnal harian, sedangkan pada sekolah kedua GPK melakukan pencataan setiap materi yang diterima oleh PDBK dan dilakukan pemetaan materi yang sudah atau belum tuntas, sehingga guru dan orang tua dapat melihat kemajuannya. Berdasarkan dari catatan tersebut, guru atau GPK melanjutkan pemberian materi selanjutnya.

Media Pembelajaran, Hamalik (1986) mengemukakan bahwa pemakaian media pembelajaran dalam proses belajar mengajar dapat membangkitkan keinginan dan minat yang baru, membangkitkan motivasi dan rangsangan kegiatan belajar, dan bahkan membawa pengaruh-pengaruh psikologis terhadap siswa. Media yang digunakan di sekolah sejauh ini masih menggunakan media yang sama dengan reguler, hanya dalam beberapa kesempatan pada sekolah kedua GPK terkadang membawa media berupa gambar diberikan kepada PDBK untuk memberikan gambaran yang lebih konkret mengenai materi yang diajarkan. Pada sekolah pertama pemanfaatan media seperti membawa tanaman, alat peraga selain membatu PDBK juga membantu peserta didik reguler untuk lebih memahamimateri.

Metode Pembelajaran, adalah suatu cara bagaimana penyampaian materi kepada peserta didik. Secara general sekolah pertama dan kedua menggunakan metode yang dipakai sama dengan reguler, yaitu ceramah, tanya jawab, penugasan dan praktek, dengan menggunakan pendekatan saintifik, namun bagi PDBK guru juga menggunakan metode peer tutor. Dimana peserta didik reguler duduk dengan PDBK dan membantu PDBK belajar. Peer tutor merupakan salah satu metode yang sering digunakan pada setting kelas inklusif karena memiliki dampak positif selain dalam aspek akademik, juga sosial dan sikap (Bolich, 2001; Frederickson \& Cline,
2009; Mallon, 2005) yang terjadi pada diri peserta didik reguler maupun PDBK. Pada aspek akademik peserta didik reguler sekaligus untuk mengulang materi dan memahami kembali, sedangkan bagi PDBK dapat memahami dengan cara yang sederhana karena materi disampaikan oleh teman. Disisi lain terbentuk sikap yang saling membantu dan menolong dan menumbuhkan rasa memahami bagi peserta didik yang reguler.

Pada sekolah pertama, dokumentasi perencanaan pembelajaran tidak dilakukan penyelarasan, namun saat pelaksanaan pembelajaran guru melakukan penyesuaian materi dan evaluasi bagi PDBK. Pelaksanaan pembelajaran sama dengan reguler hanya ada perbedaan pada kedalaman materi dan soal ujian. Sedangkan pada sekolah kedua pelaksanaan pembelajaran merujuk pada program tahunan dan PPI yang telah dikembangkan. Perencanaan pembelajaran memegang peranan untuk menguraikan tujuan pembelajaran yang akan dicapai oleh peserta didik, dan memutuskan metode, media, sumber belajar, sarana dan prasarana yang tepat untuk menciptakan pengalaman belajar yang sesuai bagi peserta didik agar tercapainya tujuan pembelajaran (Hamalik, 2013), dengan demikian ketiadaan perencanaan pembelajaran pada sekolah pertama, berakibatkan pada tidak adanya tujuan pencapaian bagi PDBK, sehingga tidak ada tuntutan bagi guru untuk memampukan PDBK mencapai tujuan tersebut, dampak bagi beberapa PDBK tidak ada tuntutan atau motivasi mencapai kemampuan yang maksimal. Pada kondisi ini, dimana tidak ada dokumentasi penyelarasan kurikulum, namun pelaksanaan pembelajaran dilakukan penyesuaian, kurikulum dipandang sebagai rencana tidak tertulis yang terdapat dalam pikiran pihak pendidikan (Taylor dalam Hamalik, 2013)

\section{Evaluasi Pembelajaran,}

Sukinah (Pratiwi, 2014) menyatakan bahwa perencanaan penilaian hasil belajar, atau evaluasi peserta didik berkebutuhan khusus di sesuaikan dengan kompetensi dan kebutuhan khusus setiap individu atau anak. Dengan demikian penilaian autentik sangat tepat untuk diterapkan bagi PDBK. Instrumen 
evaluasi pembelajaran sama dengan reguler pada penilaian akademik berupa soal tertulis atau pertanyaan lisan, sedangkan penilaian sikap dan kinerja dengan menggunakan jurnal sikap. Sekolah pertama untuk mengembangkan instrumen evaluasi dampai dengan pelaksanaannya dilakukan oleh guru kelas dengan menyederhanakan materi dan jawaban serta membantu membacakan soal bagi beberapa PDBK, sedangkan sekolah kedua pengembangan instrumen evaluasi bagi PDBK dikembangkan oleh GPK, dan pelaksanaan evaluasi bagi PDBK juga dibimbing oleh GPK. Bantuan yang diberikan saat pelaksanaan ujian bagi PDBK adalah seperti membantu membacakan soal supaya siswa lebih memahami makna soal, apabisa siswa belum bisa mengeja, maka dibantu untuk mendiktekan jawaban yang telah disebut oleh siswa.

\section{Faktor Pendukung dan Penghambat Penyelenggaraan Pendidikan Inklusif,}

Seperti yang telah dijabarkan pada tabel 2, bahwa masih ada faktor yang menghambat dalam melaksanakan pendidikan inklusif. beberapa ahli turut menyorot beberapa kendala yang dominan seperti yang sering diucapkan oleh kepala sekolah maupun guru, bahwa faktor dana dan SDM yang terbatas seringkali menjadi alasan suatu sekolah tidak atau belum melaksanakan pendidikan inklusif. Thomas, Walker, \& Webb (1998) menyebutkan aspek pendanaan menjadi salah satu faktor yang harus diperhatikan pada pendidikan inklusif, karena biaya yang dibutuhkan lebih mahal. Kebutuhan akan guru pendamping dimana jumlah peserta didik berkebutuhan khusus di sekolah meningkat sedangkan jumlah guru tetap. Di salah satu sekolah, penggajian bagi GPK didapat dari bantuan orang tua PDBK. Kekurangan SDM dan dana berakibat pada terbatasnya layanan pendidikan yang dapat diberikan. Seperti pada sekolah pertama yang belum memiliki GPK, maka guru-guru mengalami kelelahan saat mengajar dengan jumlah PDBK yang banyak dan tidak ada bantuan dari GPK sehingga pelayanan pendidikan yang diberikan tidak dapat maksimal.
Faktor lain yang cukup dominan adalah kebijakan, Stubbs (2008:72) menyatakan "kebijakan dapat menjadi dukungan dan hambatan". Kepala sekolah dan guru turut menyoroti kebijakan yang ada, saat kebijakan utama atau payung hukum pelaksanaan pendidikan inklusif sudah ada, namun kebijakan pendukung seperti dana, SDM, sarana prasarana, kurikulum masih minim dan belum dapat dipastikan kemampuan sekolah maupun pemerintah daerah untuk mengimplementasikan kebijakan tersebut. Seperti yang dikemukakan oleh GPK dan guru masih kesulitan untuk mengembangkan kurikulum yang baik bagi PDBK. Berdasarkan pada Permendiknas no 70 Tahun 2009 tentang Pendidikan Inklusif, kurikulum bagi PDBK dapat dimodifikasi untuk mengakomodasi kebutuhan dan kemampuan PDBK. Peran serta pengawas pendidikan turut mempengaruhi pengembangan modifikasi kurikulum, sebaiknya memiliki perhatian meskipun PDBK tidak berfokus pada akademik, namun juga harus memiliki pencapaian atau perkembangan dalam pembelajaran. Tentang status kepegawaian GPK turut menjadi perhatian bersama, baik kepala sekolah, guru maupun GPK berharap bahwa terdapat kejelasan tupoksi, status kepegawaian dan pengangkatan bagi GPK. Aturan mengenai beban kerja guru diatur dalam Permendikbud No 15 Tahun 2018 tentang Pemenuhan Beban Kerja Guru. Kepala Sekolah, dan Pengawas Sekolah.

Faktor pendukung selain dana dan kebijakan adalah kepemimpinan, Barret (2014) menyatakan visi dan kualitas kepemimpinan yang diberikan oleh kepala sekolah berkorelasi positif dengan keberhasilan siswa. Guru pun menyatakan bahwa dukungan dari kepala sekolah dan maupun kepala dinas pendidikan sangat berpengaruh baik dalam keberhasilan peserta didik, maupun peningkatan kualitas pendidikan disekolah tersebut.

Dari faktor pendukung dan penghambat yang ada, baik kepala sekolah, guru dan orang tua murid memberikan rekomendasi bagi pendidikan inklusif kedepannya supaya lebih diperhatikan terkait pembenahan dan kejelasan regulasi terkait dengan SDM, sarana 
prasarana, pendanaan seluruhnya supaya lebih jelas dan saling mendukung untuk kelancaran penyelenggaraan pendidikan inklusif. Mengembangkan kompetensi SDM, serta pengawasan dan pengarahan bagi halhal teknis di sekolah. Dari kedua sekolah yang diteliti, walau sama-sama menjadi sekolah contoh ditahun yang sama, namun seiring berjalannya waktu membuktikan bahwa terjadi perbedaan perkembangan pelaksaan pendidikan inklusif.

\section{PENUTUP}

Pada sekolah pertama mengenai tahapan perencanaan kurikulum guru kelas menyusun dokumen perencanaan prota, promes, silabus dan RPP yang disusun berdasarkan pada kemampuan dan kondisi peserta didik reguler. Dokumen perencanaan pembelajaran bagi PDBK belum dikembangkan. Pada tahap pelaksanaan, di kelas seluruh peserta didik dilibatkan dalam pembelajaran, namun bagi PDBK akan dilakukan penyesuaian materi, salah satu metode yang digunakan untuk membantu PDBK belajar adalah dengan tutor teman sebaya. Evaluasi hasil belajar juga dilakukan penyesuaian dengan cara membedakan tingkat kesulitan dan jumlah soal bagi PDBK sesuai dengan kemampuannya. Seluruh pembelajaran di kelas dilakukan oleh guru kelas sepenuhnya. Pada pelaksanaan ujian, guru kelas membantu beberapa PDBK membacakan soal dan beberapa PDBK yang memiliki helper dibantu oleh helper untuk menjawab setiap soalnya.

Implementasi kurikulum pada sekolah kedua, pada tahap perencanaan guru kelas menyusun perencanaan pembelajaran yang dituangkan kedalam dokumen prota, promes, silabus, dan RPP yang merujuk pada materi dan kemampuan peserta didik reguler. pembelajaran bagi PDBK disusun oleh GPK dengan melakukan assesmen, pengembangan prota, dan PPI. Penyelarasan kurikulum dilakukan dengan mendiskusikan kepada guru kelas, orang tua PDBK dan kepala sekolah. Pelaksanaan pembelajaran di kelas seluruh peserta didik dilibatkan, guru meng- usahakan supaya PDBK mampu mengikuti dan terlibat pembelajaran di kelas, namun bagi PDBK yang memiliki hambatan dan tidak memungkinkakn untuk mengikuti seperti reguler maka pembelajaran dibantu oleh GPK. Evaluasi hasil belajar bagi PDBK dilakukan penyesuaian, guru kelas menyususn soal bagi peserta didik reguler, sedangkan evaluasi PDBK dikembangkan oleh GPK disesuaikan dengan kemampuan dan kondisi peserta didik. Pelaksanaan ujian bagi PDBK yang masih membutuhkan bantuan, akan dibantu oleh GPK untuk membacakan soal ataupun mendiktekan jawaban.

Terkait faktor pendukung dan penghambat penyelenggaraan pendidikan inkusif menjadi salah satu tantangan tersendiri. Pemimpin, rekan sejawat, serta orang tua murid menjadi salah satu yang memberikan dukungan paling dominan, Sedangkan penghambat yang dominan adalah mengenai kompetensi menyelaraskan kurikulum pada guru, status kepegawaian serta kuantitas GPK yang belum sesuai dengan yang diharapkan. Faktor finansial juga menjadi salah satu kendala bagi sekolah untuk menyediakan fasilitas serta layanan yang ideal bagi PDBK. Sekolah melalui segala kelebihan dan kekurangan berjuang dan tetap berusaha semaksimal mungkin untuk memberikan layanan pendidikan yang tepat bagi PDBK.

\section{Rekomendasi}

Pemegang kebijakan dalam hal ini lembaga terkait adalah Pemerintah Pusat dan Pemerintah daerah untuk berkomitmen memfasilitasi kebutuhan sumber daya seperti penyediaan sumber daya manusia dengan melakukan pemetaan kebutuhan GPK terlebih dahulu, menyediakan kebutuhan GPK di setiap sekolah, menganggarkan dana bagi pelaksanaan pendidikan inklusif, melakukan sosialisasi kebijakan yang ada, pelatihan untuk menambah kompetensi bagi pelaksana kebijakan, dan membangun sistem yang terintegrasi untuk mendukung pelaksanaan pendidikan inklusif. Supervisi perlu dilakukan untuk meningkatkan kualitas 
pendidikan inklusif terkait dengan pengembangan kurikulum terutama dalam modifikasi kurikulum. Memberikan aturan jelas terkait dokumentasi kurikulum pendidikan inklusif yang harus dipertanggungjawabkan oleh sekolah kepada pengawas.

Sekolah dengan segala kelebihan dan keterbatasannya telah melaksanakan pendidikan inklusif. Bagi sekolah pertama kepala sekolah melakukan pembatasan maksimal kuota bagi PDBK supaya guru dapat mengontrol dan mengelola kelas dan supaya pembelajaran lebih kondusif. Melakukan kerjasama dengan pihak luar untuk mengembangkan dan melakukan program binadiri bagi PDBK. Guru supaya dapat meningkatkan kompetensi untuk lebih kreatif memberikan inovasi bagi pembelajaran di kelas yang memiliki beragam peserta didik, dan mengembangkan PPI bagi PDBK. Bagi sekolah kedua, untuk senantiasa mempertahankan mutu serta kualitas dengan terus melakukan inovasi dan meningkatkan kompetensi sesuai dengan perkembangan yang ada.

\section{DAFTAR PUSTAKA}

Abdurrahman, M. (2012). Anak berkesulitan belajar teori, diagnosis, dan remediasinya. Jakarta: PT Rineka Cipta.

Ali, M., \& Asrori, M. (2014). Metodologi dan aplikasi riset pendidikan. Jakarta: PT Bumi Aksara.

Bakken , J. P., \& Obiakor, F. E. (2016). Inclusion in general and special education in an age of change: concluding thoughts. General and Special Education Inclusion in an Age of Change: Roles of Professionals Involved Advances in Special Education, 32, 179-185. doi:10.1108/S0270401320160000032011

Barret, D. (2014). Resourcing inclusive education. Measuring Inclusive Education, 75-91. doi:10.1108/S1479363620140000003020
Bolich, B. J. (2001). Peer tutoring and social behaviors: a review. International Journal of Special Education, 16, No 2, 1-9.

Bourke, P. E. (2010). Inclusive education reform in queensland: implications for policy and practice. Taylor \& Francis: The International Journal of Inclusive Education, 183-193.

Bungin, H. B. (2013). Metodologi penelitian kuantitatif. Jakarta: Kencana.

Deklarasi Salamanca (UNESCO) tahun 1994 . (n.d.).

Direktorat Pembinaan Pendidikan Khusus Dan Layanan Khusus. (2013). Pedoman umum penyelenggaraan pendidikan inklusif. Jakarta: Direktorat Pembinaan Pendidikan Khusus Dan Layanan Khusus.

Frederickson, N., \& Cline, T. (2009). Special educational needs, inclusion and diversity (Vol. Second Edition). New York: McGraw-Hill.

Friend, M., \& Bursuck, W. D. (2015). Menuju pendidikan inklusi:panduan praktis untuk mengajar, edisi ketujuh, (terjemahan). Yogyakarta: Pustaka Pelajar.

Gagne, R. M., \& Briggs, L. J. (1979). Principles of instructional design (second ed.). USA: Holt, Rinehart and Winston.

Garnida, D. (2015). Pengantar pendidikan inklusif. Bandung: PT Refika Aditama.

Giangreco, M. F. (1997). Key lessons learned about inclusive education: summary of the 1996 schonell memorial lecture. International Journal of Disability, Development and Education, 193-206. doi:01566555/97/030193-14

Hamalik, O. (1986). Media pendidikan. Bandung: Alumni.

Hamalik, O. (2013). Dasar-dasar pengembangan kurikulum. Bandung: PT Remaja Rosdakarya.

Kiuppis, F., \& Peters, S. (2014). Inclusive education for all as a special interest within the comparative and 
international education research community. International Perspectives on Education and Society, 25, 53-63. doi:10.1108/S1479367920140000025005

Mallon, F. (2005). Peer and cross-age tutoring and mentoring schemes. In K. Topping, \& S. Maloney, The Routledge Falmer Readeer in Inclusive Education (pp. 173-187). New York: RoutledgeFalmer.

McCabe, H. (2003). The beginnings of inclusion in the people's republic of china. TASH: Research \& Practice for Persons With Severe Disabilities, Vol 28, No 1., 16-22.

McMurray, S., \& Thompson, R. (2016). Inclusion, curriculum and the rights of the child. Journal of Research in Special Educational Needs, Vol 16, No 1, 634-638. doi:10.1111/14713802.12195

Merce, C. D., \& Mercer, A. R. (1989). Teaching student with learning problems. Autralia: Merill Publishing Company A Bell \& Howel Information Company.

Miller, J., \& Seller, W. (1985). Curriculum perspectives and practice. New York: Longman Inc.

Miller-Day, M., Pettigrew, J., Hecth, M. L., Shin, Y., Graham , J., \& Krieger, J. (2013). How prevention curricula are taught under real-world conditions: types of and reasons for teacher curriculum adaptations. Health Education, 113, 324-344. doi:10.1108/09654281311329259

Mitchell, D. (2010). Review of international trends in the education of students with special educational needs. New Zealand: University of Canterbury. Retrieved from https://www.educationcounts.govt.nz /

Moleong, L. J. (2017). Metodologi penelitian kualitatif, edisi revisi. Bandung: PT Remaja Rosdakarya.

Mudjito, Elfindri, Harizal, \& Riduan, R. (2014). Pendidikan layanan khusus: model-model dan implementasi. Jakarta: Baduose Media.

Oliva, P., \& Gordon, W. (2013). Developing the curriculum, eight edition. USA: Pearson Education, Inc.

Ornstein, A., \& Hunkins, F. (2013). Curriculum foundations, principles, and issues: sixth edition. USA: Pearson Education, Inc.

Peraturan Menteri Pendidikan dan Kebudayaan No 22 Tahun 2016 tentang Standar Proses. (n.d.).

Peraturan Menteri Pendidikan Nasional No 70 Tahun 2009 Tentang Pendidikan Inklusif Bagi Peserta Didik Yang Memiliki Kelainan Dan Memiliki Potensi Kecerdasan Dan/Atau Bakat Istimewa. (n.d.).

Pratiwi, L. D. (2014). Penilaian hasil belajar matematika di sekolah penyelenggara pendidikan inklusif. Jurnal Pendidikan Khusus Fakultas Ilmu Pendidikan UNJ, 03, No 2, 1-8.

Rahmawati, E. (2014). Kompetensi guru reguler dalam melayani abk di sekolah dasar. Tesis UPI.

Richards, A., \& Dooley, E. (2015). Curriculum modifications for students with learning disabilities. Emerald Insight: In Current Perspectives on Learning Disabilitie Advances in Special Education, Vol 16, 95-111.

Rose, R., Shevlin, M., Winter, E., O'Raw, P., \& Zhao, Y. (2012). Individual education plans in the republic of ireland:an emerging system. Nasen: British Journal Of Special Education, Vol 39, No 3, 110-116.
doi:10.1111/j.1467-
8578.2012.00548.x

Rusman. (2012). Manajemen kurikulum. Jakarta: PT Raja Grafindo Persada.

Rusman. (2015). Pembelajaran tematik terpadu teori, praktik, dan penilaian. Depok: PT. RajaGrafindo Persada.

Sanjaya, W. (2008). Kurikulum dan pembelajaran: teori dan praktik pengembangan kurikulum tingkat 
satuan pendidikan (ktsp). Jakarta: Kencana.

Skjorten, M. D. (2001). Education-special needs education an introduction. Oslo: Unipubforlab.

Smaldino, S. E., Russel, J. D., Heinich, R., \& Molenda, M. (2005). Instructional media and technologies for learning. New Jersey: Englewood Cliffs.

Smith, D. J. (2015). Sekolah untuk semua teori dan implementasi inklusi: terjemahan. Bandung: Nuansa Cendekia.

Stubbs, S. (2008). Inclusive education where there are few resources. Oslo: Atlas Alliance.

Taba, H. (1962). Curriculum development theory and practice. New York: Harcourt, Brace \& World, Inc.

Thomas, G., Walker, D., \& Webb, J. (1998). Inclusive education. RoutledgeFalmers, 3-25.

Undang-Undang Dasar Negara Republik Indonesia 1945. (n.d.).

Undang-Undang No 20 Tahun 2003 Tentang Sistem Pendidikan Indonesia. (n.d.).

Valentin, J. (2007). The paeger hanbook of special education: edited by alberto m.bursztyn. US: Praeger.

Visen. (2018, Agustus 30). http://www.visen.org.uk/Learningpa ge03.html.

Wahyudin, D. (2014). Manajemen kurikulum. Bandung: PT Remaja Rosdakarya.

Walker, Z. (2016). Special education teacher preparation in singapore's dual education system. SAGE Vol.39(3), 178-190.

Westwood, P. (2001). Differentiation as a strategy for inclusive classroom practice. Australian Journal of Learning Disabilitas, 6, No 1, 5-11.

Zais, R. S. (1976). Curriculum: principles and foundations. New York: Thomas Y. Crowell Company, Inc. 